\title{
DETERMINING THE IMPACTS OF LAND COVER/USE CATEGORIES ON LAND SURFACE TEMPERATURE USING LANDSAT8-OLI
}

\author{
F. Bektas Balcik ${ }^{\text {a }}$, E. M. Ergene ${ }^{\text {a }}$ \\ ${ }^{\text {a }}$ ITU Civil Engineering Faculty, Geomatics Engineering, 34469 Maslak Istanbul, Turkey- bektasfi@itu.edu.tr
}

Commission VIII, WG VIII/3

KEY WORDS: Land Surface Temperature, Tasseled Cap Transformation, İstanbul, Landsat 8 OLI

\begin{abstract}
:
Due to unplanned and uncontrolled expansion of urban areas, rural land cover types have been replaced with artificial materials. As a result of these replacements, a wide range of negative environmental impacts seriously impacting human health, natural areas, ecosystems, climate, energy efficiency, and quality of living in town center. In this study, the impact of land surface temperature with respect to land cover and land use categories is investigated and evaluated for Istanbul, Turkey. Land surface temperature data was extracted from 21 October 2014 dated Landsat 8 OLI data using mono-window algorithm. In order to extract land use/cover information from remotely sensed data wetness, greenness and brightness components were derived using Tasseled Cap Transformation. The statistical relationship between land surface temperature and Tasseled Cap Transformation components in Istanbul was analyzed using the regression methods. Correlation between Land Surface Temperature and Meteorological Stations Temperature calculated \%74.49.
\end{abstract}

\section{INTRODUCTION}

Land surface Temperature (LST) derived from satellite remotely sensed thermal infrared (TIR) imagery is a key variable to understand the impacts of urbanization induced land use and land cover (LULC) changes.[1] Current satellite TIR data suitable for studying urban thermal environment or for solving urban environmental and health problems that are characterized by a high spatial variability have a much coarser temporal resolution than it is needed. [2] Several LST retrieval algorithms had been developed for pervious Landsat Series with single TIRs band data. The widely used Monowindow algorithm developed by Qin at al. [3] requires three essential parameters for LST retrieval from the one TIRs band data of Landsat series: ground emissivity, atmospheric transmittance and effective mean atmospheric temperature.[4]

Tasseled Cap Transformation (TCT) components can be used to determine Land Use Land Cover (LULC) categories. Brightness, Wetness and Greenness are components of TCT. Built-up areas, man-made features, roads and bare soil have high reflectance so that with brightness component these topographic features can be observed. At the same time Greenness component provides to observe healthy vegetation areas and Wetness component provides to analyze moist fields.

In this study, LST was derived with Mono-window algorithm using new generation Landsat 8 TIR and resultant LST map was analyzed and compared with TCT components for sustainable management of Istanbul.. The relationship between NDVI (Normalized Difference Vegetation Index) and LST indicates that vegetation is important in urban heat reduction. FVC (Fractional Vegetation Coverage) is also a key parameter in thermal remote-sensing analysis from which surface emissivity can be estimated, and it is an indicator of the LST, with which it has a negative linear relationship. [5]
The correlation between LST and NDVI, Greenness, Brightness and Wetness components of TCT also indicates that the negative correlation of LST and NDVI, Greenness suggests that the green land can weaken the effect on urban heat island, while the positive correlation between LST and Brightness means that the built-up land can strengthen the effect of urban heat island in our case study.[6]

\section{STUDY AREA}

Istanbul is the most crowded metropolitan city in Turkey, was chosen as study area. The city is located between at $40^{\circ}$ $58^{\prime} \mathrm{N}$ latitude and $28^{\circ} 50^{\prime} \mathrm{E}$ longitude and it lies between the continents of Europe and Asia. (Fig 1. Study Area Istanbul)

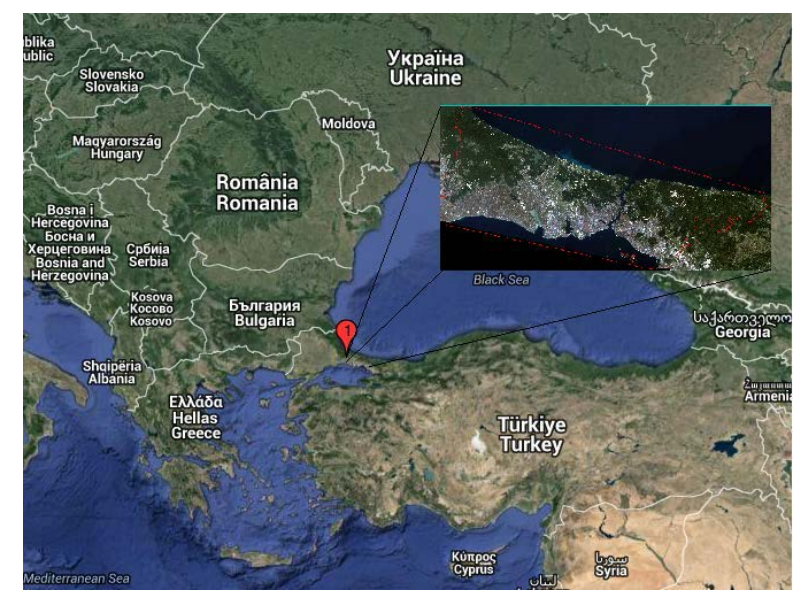

Figure 1. İstanbul is chosen as the study area.[7]

The population of Istanbul was 3 million the 1970s, 7.4 million in the 1990s, and around 13 million currently. As a result of rapid population growth and unplanned urban expansion in Istanbul, dramatic land cover changes have occurred especially within the past 65 years. Another result 
of rapid population is traffic jam problems and disorganized industrialization. This problems cause air pollution, high temperature according to seasonal averages, negative effects on population healthy etc. Because of this reason it has huge importance to determine LST distribution of the city for sustainable management. Detecting the relationship between uncontrolled expansion of urban areas, vegetation fraction and land surface temperature is important to analyze determine negative effects on Istanbul.

\section{DATA}

In this study, multispectral Landsat 8 Operational Land Imager \& Thermal Infrared Sensors (OLI \& TIRS) data acquired on 21.10.2014 was used. In this study, thermal infrared band 10 was used to obtain land surface temperature values using Mono-window algorithm [3]. Also near infrared and red bands were used to obtain Normalized Difference Vegetation Index (NDVI) values. Additionaly, band 2 (blue), band 3 (green), band 4 (red), band 5 (NIR), band 6 (SWIR1), band7 (SWIR2) were used for calculate Brightness, Greenness and Wetness components with Tasseled Cap Transformation equation [8]. The spectral intervals, spatial resolution of Landsat 8 OLI \& TIRS bands are shown in Table 1. [9] Landsat 8 imagery has a radiometric resolution of 16-bits when processed into Level-1 data products.

Meteorological data used in the study include near surface temperature and relative humidity from 15 meteorological stations in Istanbul for the same date and hour of the Landsat 8 OLI sensor image provided (October 21, 08:45 GMT). The meteorological stations belong to the Istanbul Metropolitan Municipality. These meteorological data were integrated with the mono-window algorithm to retrieve LST from Landsat 8 TIR data.

\begin{tabular}{|l|c|c|}
\hline \multicolumn{3}{|c|}{ Landsat 8 OLI \& TIRS Launched February 11, 2013} \\
\hline & $\begin{array}{c}\text { Wavelength } \\
\text { (micrometers) }\end{array}$ & $\begin{array}{c}\text { Resolution } \\
\text { (meters) }\end{array}$ \\
\hline Band 1 - Coastal aerosol & $0.43-0.45$ & 30 \\
\hline Band 2 - Blue & $0.45-0.51$ & 30 \\
\hline Band 3 - Green & $0.53-0.59$ & 30 \\
\hline Band 4 - Red & $0.64-0.67$ & 30 \\
\hline Band 5 - Near Infrared (NIR) & $0.85-0.88$ & 30 \\
\hline Band 6 - SWIR 1 & $1.57-1.65$ & 30 \\
\hline Band 7 - SWIR 2 & $2.11-2.29$ & 30 \\
\hline Band 8 - Panchromatic & $0.50-0.68$ & 15 \\
\hline Band 9 - Cirrus & $1.36-1.38$ & 30 \\
\hline Band 10 - Thermal Infrared (TIRS) 1 & $10.60-11.19$ & $100 * 30$ \\
\hline Band 11 - Thermal Infrared (TIRS) 2 & $11.50-12.51$ & $100 * 30$ \\
\hline
\end{tabular}

Table 1. Properties of Landsat 8 OLI \& TIRS [9].

\section{METHODOLOGY}

\subsection{Image Pre - Processing}

The original digital numbers (DN) of Landsat 8 OLI images were converted into exo-atmospheric reflectance based on the methods provided by Landsat 8 Data User Hand Book [10]. Landsat images were geometrically registered to the Universal Transverse Mercator projection system (ellipsoid WGS84, datum WGS84, and_zone35 ) by using 45 ground control points, primarily highway intersections, evenly distributed across the image. A first-order polynomial model was used for the rectification with a nearest neighbor resampling method. The root mean square errors were found to be less than 0.5 pixels $(15 \mathrm{~m})$ for each of the two images.

\subsection{Mono-window Algorithm}

In the present study, we used mono-window algorithm for to determine land surface temperature from 21.10.2014 Landsat 8 TIRS band 10 data.

We chosed only TIRS band 10 data because a calibration notices issued by the United States Geological Survey (USGS) indicated that data from the Landsat 8 Thermal Infrared Sensor (TIRS) band 11 have large uncertainly and suggested using TIRS band 10 data as a single spectral band for LST estimation. [4] In order to determine LST with Mono-window Algorithm, four parameters are need to be known. These are brightness temperature, effective mean temperature, atmospheric transmittance and ground emissivity. LST in the following equation (1) and Figure 2 and 3.

$\mathrm{T}_{\mathrm{S}}=\left[\mathrm{a}_{10}\left(1-\mathrm{C}_{10}-\mathrm{D}_{10}\right)+\left(\mathrm{b}_{10}\left(1-\mathrm{C}_{10}-\mathrm{D}_{10}\right)+\mathrm{C}_{10}+\mathrm{D}_{10}\right) \mathrm{T}_{10}-\mathrm{D}_{10} \mathrm{~T}_{\mathrm{a}}\right] / \mathrm{C}_{10}$

where $\quad T_{\mathrm{S}}=$ Land surface temperature

$\mathrm{Ta}=$ Effective mean atmospheric temperature

$\mathrm{T}_{10}=$ Brightness Temperature of TIRS band 10

$\mathrm{a}_{10}, \mathrm{~b}_{10}=$ Coefficients for TIRS band 10 is given[4]

$\mathrm{C}_{10}, \mathrm{D}_{10}$, =internal parameters for the algorithm was calculated using equation (2) and (3). [4]

$$
\begin{gathered}
\mathrm{C}_{10}=\tau_{10} \varepsilon_{10} \\
\mathrm{D}_{10}=\left(1-\tau_{10}\right)\left[1+\left(1-\varepsilon_{10}\right) \tau_{10}\right]
\end{gathered}
$$

where $\quad \tau_{10}=$ Atmospheric Transmittance for band 10 .

$\varepsilon_{10}=$ Emissivity for band 10. [4]

\begin{tabular}{|l|c|c|c|}
\hline Temperature Range & $\mathrm{a}_{10}$ & $\mathrm{~b}_{10}$ & $R^{2}$ \\
\hline $20{ }^{\circ} \mathrm{C}-70{ }^{\circ} \mathrm{C}$ & -70.1775 & 0.4581 & 0.9997 \\
\hline $0{ }^{\circ} \mathrm{C}-50{ }^{\circ} \mathrm{C}$ & -62.7182 & 0.4339 & 0.9996 \\
\hline $20{ }^{\circ} \mathrm{C}-30{ }^{\circ} \mathrm{C}$ & -55.4276 & 0.4086 & 0.9996 \\
\hline
\end{tabular}

Table 2. Coefficients $a_{10}$ and $b_{10}$ [4]

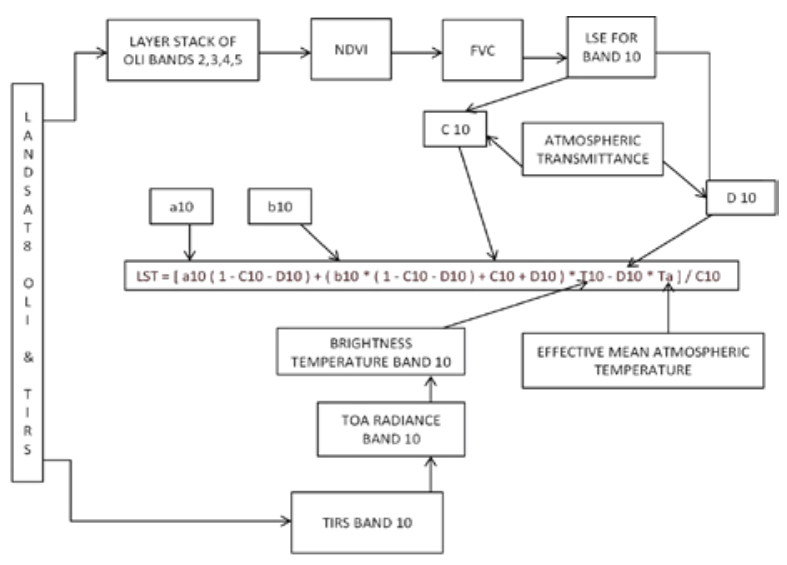

Figure 2: Flowchart of Mono-window Algorithm 


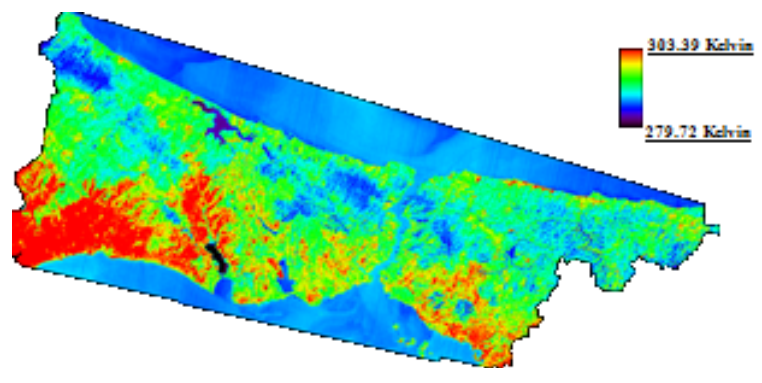

Figure 3. LST image was derived with Mono-window Algorithm.

4.2.1. Brightness Temperature: Brightness temperature (Ti) is expressed in units of the temperature of an blackbody. In order to compute brightness temperature from Landsat 8 TIRS data firstly thermal DN values of TIRS band 10 is converted into TOA Spectral Radiance and after this computed TOA Spectral radiance TIRS band 10 is transformed to brightness temperature with using $\mathrm{K}_{1}$ and $\mathrm{K}_{2}$ are band-specific thermal conversion constants. We performed with equation (4) and (5) [10]

$$
L_{\lambda}=M_{L} Q_{c a l}+A_{L}
$$

where $\quad \mathrm{L}_{\lambda}=$ TOA spectral radiance (watts $/ \mathrm{mm}^{2} * \operatorname{srad} *$ $\mu m)$

$\mathrm{M}_{\mathrm{L}}=$ Radiance_Mult_band_10

$\mathrm{A}_{\mathrm{L}}=$ Radiance_Add_band_10

$\mathrm{Q}_{\mathrm{cal}}=$ Quantized and calibrated standart product pixel values (DN)

$$
\mathrm{T}=\mathrm{K}_{2} / \operatorname{In}\left(\mathrm{K}_{1} / \mathrm{L}_{\lambda}\right)+1
$$

where $\quad \mathrm{T}=$ At-satellite brightness temperature $(\mathrm{K})$

$\mathrm{L}_{\lambda}=$ TOA spectral radiance (watts $/ \mathrm{mm}^{2} * \operatorname{srad} *$

$\mu m)$

$$
\mathrm{K}_{1}=\mathrm{K}_{1 \_ \text {constant_band_10 }}
$$$$
\mathrm{K}_{2}=\mathrm{K}_{2} \text { _constant_band_10 }
$$

Band specific thermal conversion constants $\left(\mathrm{K}_{1}\right.$ and $\left.\mathrm{K}_{2}\right)$ and band-specific multiplicative rescaling factor $\left(\mathrm{M}_{\mathrm{L}}\right)$ and additive rescaling factor $\left(\mathrm{A}_{\mathrm{L}}\right)$ were obtained from the metadata file of Landsat 8 image. (Table 3)

\begin{tabular}{|c|c|c|c|}
\hline $\begin{array}{c}\text { Thermal } \\
\text { Constant }\end{array}$ & Band 10 & $\begin{array}{c}\text { Rescaling } \\
\text { Factor }\end{array}$ & Band 10 \\
\hline K1 & 1321.08 & ML & 0.000342 \\
\hline K2 & 777.89 & AL & 0.1 \\
\hline
\end{tabular}

Table 3. Rescaling Factor and Thermal Constant values

\subsubsection{Effective Mean Atmospheric Temperature:} Effective mean atmospheric temperature $\left(T_{a}\right)$ is generally used to estimate the upwelling atmospheric radiance. Near surface air temperature $\left(\mathrm{T}_{0}\right)$ is determined from 15 local meteorological stations data. After that Near surface air temperature is used to obtain effective mean atmospheric temperature from linear relations equation mid-latitude winter is shown Table 4.

\begin{tabular}{|l|l|}
\hline \multicolumn{1}{|c|}{ Atmospheres } & Linear Relation Equation \\
\hline Tropical model & $\mathrm{T}_{\mathrm{a}}=17.9769+0.9172 \mathrm{~T}_{0}$ \\
\hline Mid-latitude summer & $\mathrm{T}_{\mathrm{a}}=16.0110+0.9262 \mathrm{~T}_{0}$ \\
\hline Mid-latitude winter & $\mathrm{T}_{\mathrm{a}}=19.2704+0.9112 \mathrm{~T}_{0}$ \\
\hline
\end{tabular}

Table 4. Lineer relation equations between effective mean atmospheric temperature and the near surface temperature.[4]

4.2.3. Atmospheric Transmittance: Atmospheric transmittance is obtained from lots of factors, such as water vapor, wavelength, ozone, aerosol etc. Atmospheric water vapor is most important to determine change of atmospheric transmittance in the thermal range of the spectrum. Atmospheric water vapor content was calculated with near surface air temperature $\left(\mathrm{T}_{0}\right)$ in Kelvin and $\mathrm{RH}$ represents relative humidity by using equation (6) [11]

$$
\omega_{\mathrm{i}}=0.0981 *\left\{10 * 0.6108 * \exp \left[\frac{17.27 *\left(\mathrm{~T}_{0}-273.15\right)}{273.3+\left(\mathrm{T}_{0}-273.15\right)}\right] R H\right\}+0.1697
$$

In this study Atmospheric transmittance was calculated using Mid-latitude winter equation (6) with atmospheric water vapor $\left(\omega_{\mathrm{i}}\right)$.

\begin{tabular}{|c|c|l|}
\hline Atmospheres & $\begin{array}{c}\text { Water Vapor } \\
\text { Content }\left(\mathrm{g}^{*} \mathrm{~cm}\right)\end{array}$ & $\begin{array}{l}\text { Transmittance } \\
\text { Estimation Equation }\end{array}$ \\
\hline \multirow{2}{*}{$\begin{array}{c}\text { Mid- latitude } \\
\text { summer }\end{array}$} & $0.2-1.6$ & $\tau_{10}=0.9184-0.0725 \omega_{\mathrm{i}}$ \\
\cline { 2 - 3 } & $1.6-4.4$ & $\tau_{10}=1.0163-0.1330 \omega_{\mathrm{i}}$ \\
\cline { 2 - 3 } & $4.4-5.4$ & $\tau_{10}=0.7029-0.0620 \omega_{\mathrm{i}}$ \\
\hline \multirow{2}{*}{$\begin{array}{c}\text { Tropical } \\
\text { model }\end{array}$} & $0.2-2.0$ & $\tau_{10}=0.9220-0.0780 \omega_{\mathrm{i}}$ \\
\cline { 2 - 3 } & $2.0-5.6$ & $\tau_{10}=1.0222-0.1310 \omega_{\mathrm{i}}$ \\
\cline { 2 - 3 } $\begin{array}{c}\text { Mid- latitude } \\
\text { winter }\end{array}$ & $5.6-6.8$ & $\tau_{10}=0.5422-0.0440 \omega_{\mathrm{i}}$ \\
\hline \multicolumn{2}{|c}{} & $\tau_{10}=0.9228-0.0735 \omega_{\mathrm{i}}$ \\
\hline
\end{tabular}

Table 5. Derivation of atmospheric transmittance for Landsat8 TIRS band.[4]

4.2.4. Ground Emissivity: In this study we was used NDVI threshold method to estimate Land surface emissivity (LSE) from Landsat 8 imagery as the following Table 6 and Table 7.

\begin{tabular}{|l|l|}
\hline \multicolumn{1}{|c|}{ Equations } & \multicolumn{1}{c|}{ Conditions } \\
\hline$\varepsilon=\alpha+$ bored & FVC $=0$ \\
\hline$\varepsilon=\varepsilon_{\mathrm{S}}(1-\mathrm{FVC})+\varepsilon_{\mathrm{V}} \mathrm{FVC}$ & $0<\mathrm{FVC}<1$ \\
\hline$\varepsilon=0.99$ & $\mathrm{FVC}=1$ \\
\hline
\end{tabular}

Table 6. Equations and Conditions for estimating LSE with FVC according to NDVI threshold method.[12]

\begin{tabular}{|l|l|}
\hline \multicolumn{1}{|c|}{ Land Cover } & \multicolumn{1}{c|}{ Expression } \\
\hline FVC $=0$ & $0.979-0.046 \mathrm{r}$ \\
\hline $0<$ FVC $<1$ & $0.971(1-\mathrm{FVC})+0.987 \mathrm{FVC}$ \\
\hline water & 0.991 \\
\hline Snow/Ice & 0.986 \\
\hline
\end{tabular}

Table 7. Expressions with reference to Conditions for TIRS 1 band 10.[12] 
where

pred $=$ Reflectance in the red band (band 4)

$\varepsilon_{\mathrm{S}}$ and $\varepsilon_{\mathrm{V}}=$ Soil and vegetation emissivity values.

Normalized different vegetation index (NDVI) is performed from band 4 (red) and band 5 (NIR) using algorithm shown in equation (7) [12] after layer stacking of band 2,3,4,5. is shown in Figure 4.

$$
\text { NDVI }=(\text { NIR-RED) } /(\text { NIR+RED })
$$

NDVI image is reclassified to calculate NDVI $_{\text {Sor }}$ is 0.2 and $\mathrm{NDVI}_{\text {VEGETATION }}$ is 0.53 .

Land Surface Emissivity (LSE) is estimated depending on Fractional Vegetation Cover (FVC) for a pixel. FVC is calculated with equation (8) [12].

$\mathrm{FVC}=\left(\mathrm{NDVI}-\mathrm{NDVI}_{\mathrm{SOIL}}\right) /\left(\mathrm{NDVI}_{\text {VEGETATION }}-\mathrm{NDVI}_{\text {SOIL }}\right)(8)$

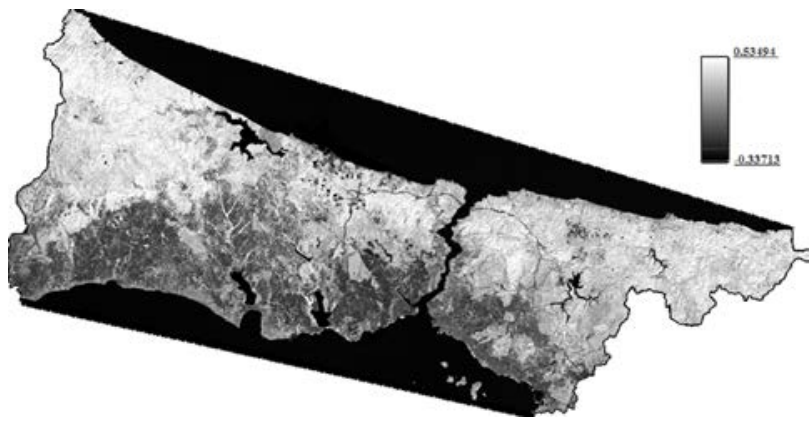

Figure 4. NDVI image.

\subsection{Tasseled Cap Transformation}

Tasseled Cap Transformation is called for its cap shape. In general, the Brightness Component, Greenness Component and Wetness Component derived from TCT can explained over $90 \%$ of the spectral variance of individual scenes.

Brightness responds to the physical properties that influence total reflectance. Greenness is responsive to the characteristic of health green vegetation that is the combination of high absorbtion of chrophyll in the visible bands and high reflectance of leaf structure in the near-infrared band. Wetness responds to the amount of moisture being held by the vegetation or soil.

Brightness, Wetness, Greenness Components were calculated with tansform equation (9) and necessary coefficient for to use in this transform equation is shown Table 9 [8]. Landsat 8 OLI bands firstly convert into TOA planetary reflectance after that the components were obtained. Brightness, Wetness, Greenness images are shown Figure 5.

\begin{tabular}{|l|l|l|l|l|l|l|}
\hline \multirow{2}{*}{ Index } & $\begin{array}{l}\text { Band } \\
2 \\
\text { (Blue) }\end{array}$ & $\begin{array}{l}\text { Band } \\
\text { (Green) }\end{array}$ & $\begin{array}{l}\text { Band } \\
\text { (Red) }\end{array}$ & $\begin{array}{l}\text { Band } \\
5 \\
\text { (NIR) }\end{array}$ & $\begin{array}{l}\text { Band } \\
6\end{array}$ & $\begin{array}{l}\text { BWIR1 } \\
7\end{array}$ \\
\hline Brightness & 0.3029 & 0.2786 & 0.4733 & 0.5599 & 0.508 & 0.1872 \\
\hline Greenness & -0.2941 & -0.243 & -0.5424 & 0.7276 & 0.0713 & -0.1608 \\
\hline Wetness & 0.1511 & 0.1973 & 0.3283 & 0.3407 & -0.7117 & -0.4559 \\
\hline
\end{tabular}

Table 8. TCT Coefficients according to band number for Landsat 8 OLI [8]
$\mathrm{TCT}_{\mathrm{I}}=\left(\operatorname{coeff}_{2} *\right.$ band2 $)+\left(\operatorname{coeff}_{3} *\right.$ band 3$)+\left(\operatorname{coeff}_{4} *\right.$ band 4$)+\left(\right.$ coeff $_{5} *$ band5 $)+\left(\operatorname{coeff}_{6} *\right.$ band6 $)+\left(\operatorname{coeff}_{7} *\right.$ band7)

where $\quad \mathrm{TCT}_{\mathrm{I}}=$ Tasseled Cap Transformation Component

band2,3,4,5,6,7 = Landsat OLI bands TOA planetary reflectance. [13]

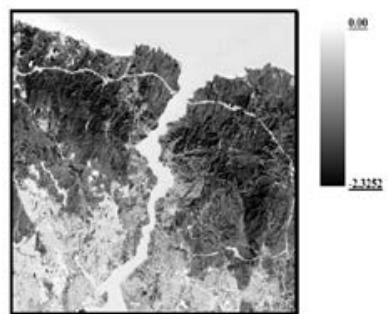

(a) Briction
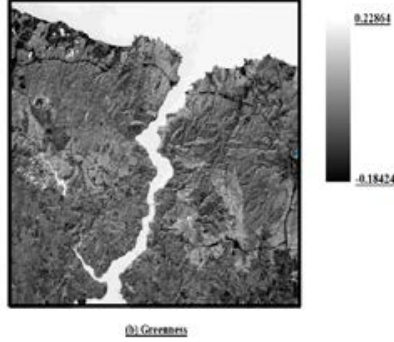

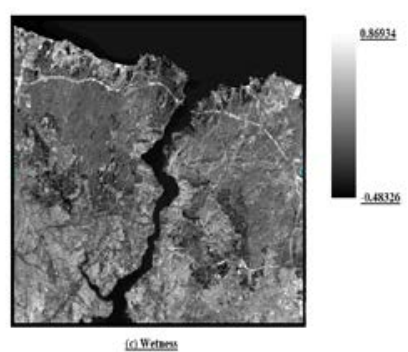

Figure 5. Sample area from TCT Brightness, Greenness, Wetness images for Landsat 8 OLI

\section{Analysis and Comparision}

In this present study, fifteen different Meteorogical stations data was used for to calculate effective mean surface temperature and water vapor content as a near surface temperature. After that effective mean surface temperature and water vapor used for derivative LST with Mono-window algorithm. For the accuracy verification we calculated correlation between meteorological stations temperatures and Mono-window Algorithm LST temperatures and we obtained \%74.49 correlation is shown Table 9. Relation between this two temperature is shown Figure 6.

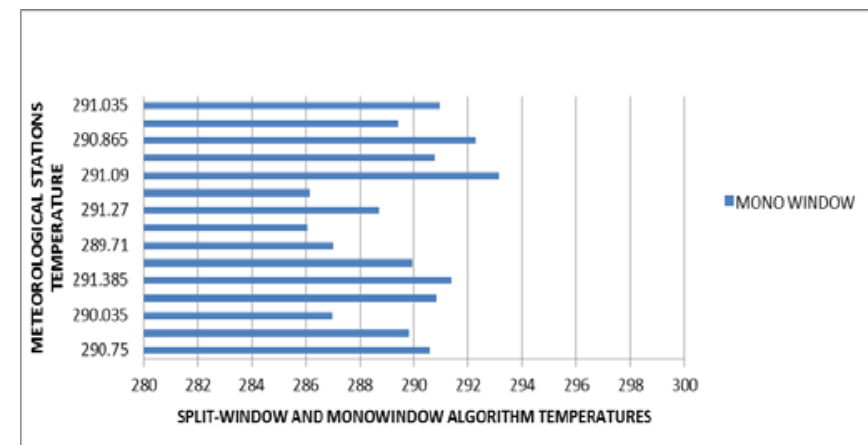

Figure 6. Relation between Meteorogical Stations Temperature and Mono-window Algorithm LST Temperatures. 


\begin{tabular}{|c|c|c|c|c|}
\hline METEOROLOGICALSTATIONS & LATITUDE & LONGITUDE & TEMPERATURE (K) & $\begin{array}{c}\text { MONO-WINDOW } \\
\text { TEMPERATURE (K) }\end{array}$ \\
\hline BEYKOZ & $417^{\prime} 54.54^{\prime \prime}$ & $297^{\prime} 51.16^{\prime \prime}$ & 289.710 & 287.003 \\
\hline BEYLIKDUZU & $410^{\prime} 20.77^{\prime \prime}$ & $2840^{\prime} 25.11^{\prime \prime}$ & 289.950 & 286.068 \\
\hline ARNAVUTKOY & $4110^{\prime} 29.3^{\prime \prime}$ & $2845^{\prime} 12.93^{\prime \prime}$ & 290.035 & 286.998 \\
\hline MAHMUTBEY & $413^{\prime} 49.19^{\prime \prime}$ & $2820^{\prime} 54.64^{\prime \prime}$ & 290.240 & 286.15 \\
\hline UMRANIYE & $411^{\prime} 49^{\prime \prime}$ & $297^{\prime} 15.16^{\prime \prime}$ & 290.385 & 289.401 \\
\hline BESIKTAS & $413^{\prime} 12.67^{\prime \prime}$ & $290^{\prime} 31.81^{\prime \prime}$ & 290.410 & 289.928 \\
\hline ATASEHIR & $410^{\prime} 16.16^{\prime \prime}$ & $296^{\prime} 5.66^{\prime \prime}$ & 290.510 & 290.84 \\
\hline AHL_BAKIRKOY & $4059^{\prime} 35.79^{\prime \prime}$ & $2849^{\prime} 3.55^{\prime \prime}$ & 290.750 & 290.562 \\
\hline PENDIK & $4053^{\prime} 22.27^{\prime \prime}$ & $2914^{\prime} 13.57^{\prime \prime}$ & 290.865 & 292.277 \\
\hline ALEMDAG & $412^{\prime} 29.19^{\prime \prime}$ & $2916^{\prime} 25.38^{\prime \prime}$ & 290.970 & 289.835 \\
\hline ZINCIRLIKUYU & $414^{\prime} 0.17^{\prime \prime}$ & $290^{\prime} 46.87^{\prime \prime}$ & 291.035 & 290.954 \\
\hline KINALI & $417^{\prime} 28.65^{\prime \prime}$ & $2810^{\prime} 4^{\prime \prime}$ & 291.090 & 293.122 \\
\hline SARIYER & $418^{\prime} 25.72^{\prime \prime}$ & $291^{\prime} 39.46^{\prime \prime}$ & 291.270 & 288.714 \\
\hline TUZLA & $4052^{\prime} 35.7^{\prime \prime}$ & $2923^{\prime} 17.66^{\prime \prime}$ & 291.385 & 291.384 \\
\hline & & & CORRELATION & 0.744955814 \\
\hline
\end{tabular}

Table 9. Correlation between LST Temperature and Meteorological Stations Temperature

In this study, TCT method was applied to reflectance of Landsat 8 OLI bands by using derived TCT coefficients to calculate brightness, greenness and wetness.

Brightness component is a weighted sum of all the bands and accounts for the most variability in the image. It is typically associated with bare or partially covered soil, natural and man-made features and variations in topography. [9] In Figure 5 (a) image shows brightness and built up areas, roads, concrete structure and soil without vegetation are shown as lighter gray or approximately white according to other topographic features. At the same time Table 10 show us when brightness component's values increase, LST also increase. So between brightness component and LST have linear increasing relation Figure 7.

\begin{tabular}{|c|c|c|c|c|c|c|c|}
\hline METEOROLOGICAL STATION & TEMPERATURE & RELATIVE HUMIDITY & KELVIN & MW & BRIGHTNESS & GREENNESS & WETNESS \\
\hline BEYKOZ & 16.56 & 52.22 & 289.71 & 287.003 & -0.304 & -0.063 & -0.017 \\
\hline BEYLKDUZU & 16.8 & 100 & 289.95 & 286.068 & -0.248 & -0.052 & -0.006 \\
\hline ARNAVUTKOY & 16.885 & 99.85 & 290.035 & 286.998 & -0.234 & -0.047 & -0.004 \\
\hline MAHMUTBEY & 17.09 & 56.64 & 290.24 & 286.15 & -0.221 & -0.027 & -0.003 \\
\hline UMRANIYE & 17.235 & 52.085 & 290.385 & 289.401 & -0.218 & -0.019 & -0.002 \\
\hline BESIKTAS & 17.26 & 49.355 & 290.41 & 289.928 & -0.217 & -0.013 & 0.001 \\
\hline ATASEHIR & 17.36 & 72.065 & 290.51 & 290.84 & -0.187 & 0.002 & 0.01 \\
\hline BAKIRKOY & 17.6 & 53.955 & 290.75 & 290.562 & -0.18 & 0.003 & 0.014 \\
\hline PENDIK & 17.715 & 45.94 & 290.865 & 292.277 & -0.178 & 0.007 & 0.017 \\
\hline ALEMDAR & 17.82 & 44.095 & 290.97 & 289.835 & -0.08 & 0.037 & 0.038 \\
\hline ZINCIRLKUYU & 17.885 & 47.83 & 291.035 & 290.954 & -0.16 & 0.023 & 0.022 \\
\hline KINALI & 17.94 & 73.255 & 291.09 & 293.122 & -0.157 & 0.026 & 0.023 \\
\hline SARIYER & 18.12 & 52.82 & 291.27 & 288.714 & -0.156 & 0.032 & 0.029 \\
\hline TUZLA & 18.235 & 60.32 & 291.385 & 291.384 & -0.124 & 0.034 & 0.029 \\
\hline MASLAK & 18.685 & 48.4 & 291.835 & 290.783 & -0.166 & 0.007 & 0.019 \\
\hline
\end{tabular}

Table 10. Relation Between Greenness, Brightness and LST values for same coordinate locations.

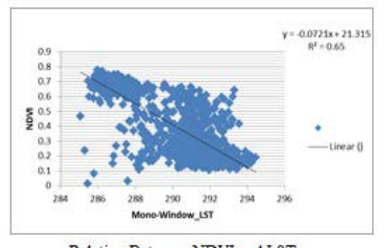

Relation Between NDVI and LST

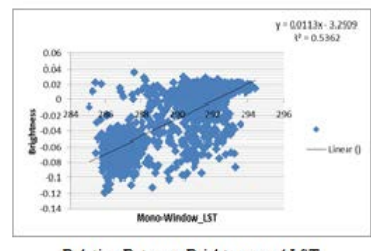

Relation Between Brightness and LST

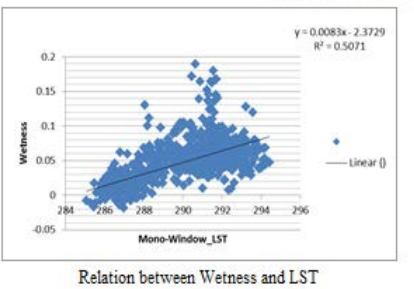

Figure 7. Relation Between Brightness,NDVI,Wetness and LST.
Greenness is a measure of the contrast between the NIR band and the visible bands due to the scattering of infrared radiation resulting from the cellular structure of green vegetation and the absorption of visible radiation by plant pigments. [9] We can observe relation between greenness image and LST image is linearly discreasing from Table 10. On vegetation areas greenness values is observed higher than other features at the same time LST values is lower on same areas with Greenness. Actually NDVI and Greenness components show same behavior for estimate kind of vegetation areas and NDVI have same relation with LST. NDVI and LST have linearly discreasing (negative) relation too. We can observe it From Figure 7.

Wetness relates to soil moisture, canopy, water and other moisture features and it is orthogonal to brightness and greenness. In Figure 7 show us relation between wetness and LST is linearly increasing.

\section{Conclusion}

According to correlation results between Meteorological Stations and Mono-Window algorithm; correlation of MonoWindow Algorithm is \%70.224.

Land Surface Temperature has negative linear relation with NDVI and Greenness component of TCT while it has positive linear relation with Brightness and Wetness. This situtation show to us, built up areas cause higher surface temperature than daily average surface temperature. On the other hand, vegetation areas provide lower surface temperature according to the daily average surface temperature.

Not only built up areas cause higher surface temperature but also bare lands without vegetation on surface show us high surface temperature like built up areas because of albedo effect.

\section{Acknowledgments}

We would like to thank the state Meteorological Office of Turkey and the Istanbul Metropolitan Municipality for providing meteorological station data and USGS/Earth Explorer for freely available Landsat 8 OLI \& TIRs data.

\section{References}

[1] Fu P., Weng Q. A time series analysis of urbanization induced land use and land cover change and its impact on land surface temperature with Landsat imagery, Remote Sensing of Environment 175 (2016) 205-214,15 Jan. 2016

[2] Weng Q., Fu P., Gao F. Generating daily land surface temperature at Landsat resolution by fusing Landsat and MODIS data, Remote Sensing of Environment 145 (2014) 55-67, 22 Feb. 2014

[3] Qin, Z.; Karnieli, A.; Berliner, P. A mono-window algorithm for retrieving land surface temperature from Landsat TM data and its application to the Israel-Egypt border region. Int. J. Remote Sens. 2001, 22, 3719-3746.

[4] Wang F., Qin Z., Song C., Tu L., Karnieli A.,Zhao S., An Improved Mono-Window Algorithm for Land Surface Temperature Retrieval from Landsat 8 Thermal Infrared Sensor Data, Remote Sens. 2015, 7, 4268-4289. 
[5] Zhang Y., Chen L., Wang Y., Chen L., Yao F., Wu P., Wang B., Li Y., Zhou T., Zhang T., Research on the Contribution of Urban Land Surface Moisture to the Alleviation Effect of Urban Land Surface Heat Based on Landsat 8 Data, Remote Sens. 2015, 7, 10737-10762

[6] Lin L., Zhang Y., Urban Heat Island Analysis Using the Landsat TM Data and ASTER Data: A Case Study in Hong Kong, Remote Sens. 2011, 3, 1535-1552.

[7] [URL 1] http://earthexplorer.usgs.gov/ Received date: 7 Apr.2016

[8] Baiga M. H. A., Zhanga L., Shuaia T., Tonga Q., Derivation of a tasselled cap transformation based on Landsat 8 at-satellite reflectance, Remote Sensing Letters, 2014 Vol. 5, No. 5, 423-431.

[9][URL2]http://landsat.usgs.gov/band_designations_landsat satellites.php Received date: 7 Apr. 2016

[10][URL3]http://landsat.usgs.gov/Landsat8_Using_Product. php Recived date: 24 March 2016

[11] Balcik F. B., Determining the impact of urban components on land surface temperature of Istanbul by using remote sensing indices. Environ. Monit. Assess. (2014) 186:859-872.

[12] Skoković D., Sobrino J.A., Jiménez-Muñoz J. C., Sòria G., Juşien Y., Mattar C., Cristóbal J., Calibration and Validation of land surface temperature for Landsat8- TIRS sensor, LPVE (Land Product Validation and Evolution, ESA/ESRIN Frascati (Italy). January 28-30, 2014.

[13] [URL 3] http://grindgis.com/blog/vegetation-indicesarcgis Recieve date: 25 March 2016 